\title{
ACUTE AND LATENT INFECTION IN MICE WITH A VIRULENT STRAIN OF AUJESZKY'S DISEASE VIRUS
}

\author{
Roberto B. Flatschart; Maurício Resende* \\ Laboratório de Virologia Comparada, Departamento de Microbiologia, Instituto de Ciências \\ Biológicas, Universidade Federal de Minas Gerais, Brasil
}

Submitted: January 07, 1999; Returned to authors for corrections: October 20, 1999; Approved: October 06, 2000

\begin{abstract}
Acute and latent infections with the Brazilian LA031 strain of Aujeszky's disease virus (ADV) were established in mice. Ultraviolet irradiated ADV administered subcutaneously was a successful way to establish latent infection. The presence of ADV was detected by PCR. Two sets of 22-mer primers were synthesized and used to amplify gG glycoprotein gene sequences in acute and latent infected trigeminal nerve ganglia. The specificity of the amplification was verified by dot-blot hybridization.
\end{abstract}

Key words: Aujeszky's disease virus, polymerase chain reaction, dot-blot hybridization

\section{INTRODUCTION}

Aujeszky disease virus (ADV), the causative agent of Aujeszky disease (AD), is an important pathogen in swine. The disease is characterized by a wide spectrum of clinical manifestations, including nervous and respiratory symptoms. A characteristic of $\mathrm{AD}$ is that the acute phase of the disease is frequently followed by life long latency $(4,14,15,20)$ and transmission to uninfected animals occurs regardless the presence of serum antibodies (3). Eradication campaigns have been undertaken in a number of countries (21). Considerable effort was devoted to understand the ADV latency at cellular and molecular levels. The mechanisms of maintenance and reactivation of the latent state in swine are poorly understood at the present time and the true epidemiological significance of latency in swine has not been unequivocally proved. Determining the occurrence of ADV latency requires a sensitive assay system and the polymerase chain reaction (PCR) makes possible the amplification of rare DNA sequences $(1,11,23)$.

The mice have been useful in developing laboratory models of latency for alphaherpesviruses, including $\operatorname{ADV}(8,17,19)$. As a sensitive host, the mouse has been also used to characterize ADV strains $(7,22)$.
This report describes the establishment of acute and latent infection in mice with a virulent Brazilian strain of ADV, the establishment of latency in trigeminal nerve ganglia and the application of PCR for the detection of ADV DNA sequences. The specificity of the amplification was verified by dot-blot hybridization.

\section{MATERIALS AND METHODS}

Mice. BALB/c mice were bred on site and maintained as a randomly bred closed colony.

Virus. The ADV strain LA031, isolated from the tonsils and spleen of a 30 day-old piglet coming from a herd in which the $\mathrm{AD}$ was detected, was provided by Dr. C. H. Panzenhagen, LARA Pedro Leopoldo, MG (5). This strain was maintained in a mycoplasma free swine kidney cell line (SK-6). The growth medium consisted of Dulbecco's Modified Eagle's Medium (DMEM) with $2 \mathrm{mM}$ glutamine, $15 \mathrm{mM}$ HEPES, supplemented with $10 \%$ fetal bovine serum, gentamicin $(50 \mu \mathrm{g} / \mathrm{ml})$ and amphotericin B $(2.5 \mu \mathrm{g} /$ $\mathrm{ml})$. The SK-6 monolayers were inoculated at a multiplicity of infection (MOI) of $0.01 \mathrm{TCID}_{50} /$ cell. The virus containing medium was clarified by low speed centrifugation and the cell-free medium titrated by the microtiter method (13).

\footnotetext{
* Corresponding author. Mailing Address: LVC, Departamento de Microbiologia, ICB, UFMG, Caixa Postal 486, CEP 30161.970, Belo Horizonte, MG, Brasil. E-mail: mresende@mono.icb.ufmg.br.
} 
Infection of experimental mice. Only six weeks old female mice were used. They were divided into two experimental groups of ten animals (A, B) and housed in separate cages. Care of the mice was provided according to the guidelines for use and care of laboratory animals of UFAW (24). Mice food and tap water were provided ad libitum. Each mouse in group A received by the subcutaneous route $0.1 \mathrm{ml}$ of ultraviolet inactivated LA031 strain of ADV (titer ${ }^{3}$ $\left.10^{7} \mathrm{TCID}_{50} / \mathrm{ml}\right)$. The viral suspension $(10 \mathrm{ml})$ was placed in a plastic Petri dish $(150 \mathrm{~mm})$ with gentle rocking and then UV irradiated for $30 \mathrm{sec}$ with germicidal UV lamp (G15T8) at a fluency rate of $0.9 \mathrm{w} / \mathrm{m} 2$. UV light fluency was measured by using a Black-Ray UV meter (UV Products Inc., San Gabriel, CA, USA). Group B was given by the subcutaneous route $0.1 \mathrm{ml}$ of phosphate-buffered saline and the same kind of inoculation was done three weeks later. The last dose four weeks later was in the same fashion as group A, $0.1 \mathrm{ml}$ of virulent LA031 strain of ADV (titer $10^{7} \mathrm{TCID}_{50} / \mathrm{ml}$ ) subcutaneously in the right rear leg. The ADV serologic status of all mice (group A and B) was assessed by ELISA using serum samples collected by tail bleeding at the time of inoculation with virulent virus (6).

ADV detection in the experimental mice. Mice (groups A and $\mathrm{B}$ ) were examined daily for characteristic signs of $\mathrm{AD}$ or death. Surviving mice were kept in isolation for 60 days postinoculation and then euthanized with chloroform. The trigeminal nerve ganglia of dead or killed mice were collected and placed on ice in TEN (10 mM Tris-HCl, pH 8.0; 1 mM EDTA; $10 \mathrm{mM}$ $\mathrm{NaCl})$. Homogenization was carried out by placing the ganglia in a sterile $2.0 \mathrm{ml}$ glass homogenizer containing $0.2 \mathrm{ml}$ of TEN. The trigeminal nerve ganglia were homogenized completely using ten stokes of the plunger. Cell debris were pelleted by centrifugation at $2000 \mathrm{x}$ g for $10 \mathrm{~min}$. The supernatant was adjusted to $1 \%$ Nonidet $\mathrm{P} 40,1.0 \mathrm{mg}$ proteinase $\mathrm{K} / \mathrm{ml}$ and incubated at $55^{\circ} \mathrm{C}$ for $1-3$ hours.

ELISA. Dynatech Immulon 96 well plates were used in the indirect ELISA performed as described elsewhere (6). The highest dilution which gave a distinct measurable difference between the control (uninoculated mouse) and the test serum was taken as the titer.

Sample preparation for PCR. The proteinase K digestion tube was cooled off and $0.1 \mathrm{ml} 5.0 \mathrm{M} \mathrm{KAc}$ was added. After $30 \mathrm{~min}$. on ice, sediment was pelleted by centrifugation and the supernatant collected in a new tube and the DNA precipitated with ethanol. The precipitate was dissolved in $10 \mathrm{mM}$ Tris- $\mathrm{HCl}$, pH 7.4, 1 mM EDTA with $1 \mu \mathrm{g} / \mathrm{ml}$ RNase.

DNA amplification. Primers were selected from the nucleotide sequence flanking the $260 \mathrm{bp}$ sequence located within the Bam HI Q fragment containing the sequences of the $\mathrm{ADV}$ gG gene (16). Primer designations and sequences were: LVCA1 5' CACAGCTCAACAATGAAGTGGG (22 mer) and LVCA2 5' TCCGAGGAGCGGGACGATACGT (22 mer). PCR amplification was carried out in a final volume of $50 \mu \mathrm{l}$. Viral DNA (200 to $500 \mathrm{ng}$ ) was added to amplification mix (1X Taq polymerase buffer - $10 \mathrm{mM}$ Tris- $\mathrm{HCl} \mathrm{pH} 8.3,50 \mathrm{mM} \mathrm{KCl}, 1.5 \mathrm{mM}$ $\mathrm{MgCl}_{2}, 0.001 \%$ gelatine, $0.5 \%$ Tween 20 and $10 \%$ glycerol), $100 \mu \mathrm{M}$ of each dNTP and $20 \mathrm{pmol}$ of each primer. Two rounds of cycle reactions were set. The first round was performed with a denaturation step at $95^{\circ} \mathrm{C}$ for $1 \mathrm{~min}$, annealing at $47^{\circ} \mathrm{C}$ for $1 \mathrm{~min}$. and extension at $72^{\circ} \mathrm{C}$ for $1 \mathrm{~min}$. This was followed by a second round of 30 thermal cycle reactions of denaturation at $94^{\circ} \mathrm{C}$ for $1 \mathrm{~min}$., annealing at $58^{\circ} \mathrm{C}$ for $1 \mathrm{~min}$ and extension at $72^{\circ} \mathrm{C}$ for $1 \mathrm{~min}$. The last cycle was followed by an extended polymerisation step for $5 \mathrm{~min}$ at $72^{\circ} \mathrm{C}$.

Electrophoresis of the PCR products. To visualize the amplification yield, $15 \mu 1$ amounts of the PCR products were run on $2.0 \%$ agarose gels at $100 \mathrm{~V}$ for $45 \mathrm{~min}$ in TBE $0.5 \mathrm{X}$. To analyse the PCR products the gels were stained with ethidium bromide (9).

Hybridization of the PCR products. To control the specificity of the amplification, the PCR products were analysed by both electrophoresis and DNA dot-blot hybridization. Briefly, $3.0 \mu 1$ of the amplification mixture were spotted on a nitrocellulose membrane filter (Life Technologies) in a Dot-Blot apparatus manifold (Life Technologies, Gaithersburg). The filter was prehybridised in 6 X SSC $(0.03 \mathrm{M}$ sodium citrate, $0.3 \mathrm{M} \mathrm{NaCl}$ ), $0.5 \% \mathrm{SDS}, 0.1 \% \mathrm{BSA} 5 \mathrm{X}$ Denhart's solution and $100 \mu \mathrm{g} / \mathrm{ml}$ denaturated salmon sperm DNA for $3 \mathrm{~h}$ at $56^{\circ} \mathrm{C}$. Hybridization was carried out in the same solution, only salmon sperm DNA was substituted by a biotin labelled probe. The filter was incubated at $45^{\circ} \mathrm{C}$ for $18 \mathrm{~h}$. Three washing steps, of $30 \mathrm{~min}$ each, were carried out at $45^{\circ} \mathrm{C}$ in $2 \mathrm{X} \mathrm{SSC}$. The signals of the biotin label were detected as described in the protocol of Life Technologies (Gaithersburg, MD). The hybridization probe was prepared by digesting the $260 \mathrm{bp}$ amplified product with Bam HI to produce a 196 bp internal fragment. Following digestion, the probe reaction mixture was prepared by a procedure using the Glassmax DNA isolation system (Life Techologies, Inc) to produce the purified fragment. This fragment was labelled with biotin- 7-dATP by nick translation using the recommended protocol (LifeTechnologies).

\section{RESULTS}

Clinical observations of experimental mice. All mice in group A exhibited positive ADV serologic status by ELISA (OD values between 0.43 and 0.672 ) by the time of challenge and all mice in group $B$ showed no detectable level of antibodies (OD values below 0.152). In group A, no clinical signs were observed after exposure to virulent virus. All mice in group B were severely affected and died 6-7 days after receiving infective virus, showing characteristic signs of $\mathrm{AD}$ infection. These signs 
included cycles of prostation and hyperexcitability, anorexia, ataxia, paresis, paraplegia and pruritus.

Amplification of ADV DNA. Amplification with primers LVC A1 and A2 yielded a PCR product of $260 \mathrm{bp}$. This product was clearly visualized as a sharp band on agarose gels (Figs. $1 \mathrm{~A}$ e 1B) on all trigeminal nerve ganglia collected three weeks after challenge of group A mice and also in group B mice collected at the time of death. No amplification was detected in the DNA control sample from BHV-1 and SK-6 cells.

Hybridization of the PCR products. Analysis with the specific probe by means of dot-blot hybridization hybridized to all amplification products placed on a nylon membrane. No hybridization was observed in the BHV-1 and SK-6 DNA (Fig. $1 \mathrm{C})$.

\section{DISCUSSION}

In swine the serum virus neutralization antibody titer induced by vaccination has little predictive value on the degree of protective immunity provided by ADV vaccines. Vaccine efficacy is best evaluated by comparing the effects that challenge exposure to virus has on vaccinated and control animals under standard laboratory conditions (10). For ADV vaccines, a challenge dose of virus sufficient to cause dysfunction or death in $80 \%$ of control pigs is desired. The severity of signs following challenge exposure depends on the virulence of the viral strain, dose of virus and route of exposure (12). The LA031 strain of ADV can be considered a classical example of a Brazilian virulent strain. This strain has been studied before and its DNA fingerprinting has been previously reported (5). Inoculated mice (group A) with detectable level of antibody at the time of challenge were protected. In contrast, all mice in group B that had no detectable level of antibody developed clinical signs of ADV and died. In group A, where there was no evidence of disease, the trigeminal nerve ganglia were shown to contain latent ADV when examined by PCR. The UV inactivated virus conferred good protection against disease but the challenge virus did replicate in these animals and was able to establish latency in the trigeminal nerve ganglia. Our findings in mice support the contention stated before that successful vaccination of swine against ADV does not prevent superinfection (10). Further experiments with other animal herpesviruses, such as those for infectious bovine rhinotracheitis and Marek's disease, does not prevent reinfection either. In our experience (data not shown), the characteristics of the model will be influenced by the choosen challenge virus strain, the route of infection and the presence of preexisting neutralizing antibodies. Our data suggest that exposing animals by subcutaneous route, avoiding antibodies at the mucosal level, even in the presence of circulating antibodies, is not enough to prevent replication of the challenge virus.
Other goals in this experiment were to set a simple means to successfully establish latency and provide a sensitive and convenient detection method for acute and latent infection. The results of the present study indicate the potential usefulness of the PCR using primer sequences derived from the $\mathrm{gG}$ gene as a mean of detecting ADV infection. Dot-blot hybridization further confirmed the specificity of amplification. The present experiment indicates that the probe, when hybridized to PCR products, provides specificity and sensitivity and does not cross-hybridize with other members within the family Herpesviridae, as described before (2).

The present mouse model of acute and latent ADV infection differs from other model, already published in that they used passive transfer of antibody, nasal or conjunctival route of inoculation and gI- swine non virulent ADV strain Bartha (17). In contrast, we provide evidence that a full virulent

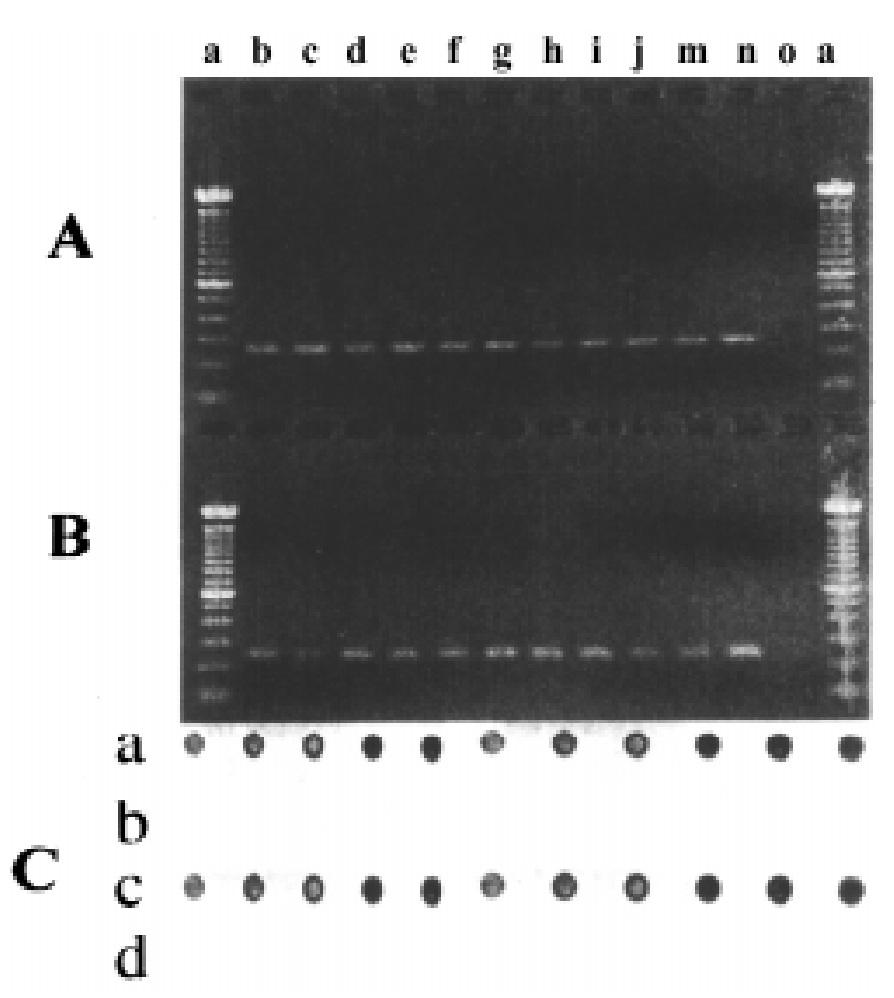

Figure 1. Detection of ADV DNA in trigemial nerve ganglia. Panel A: PCR amplification of gG sequences of latently infected mice (lanes $\mathrm{c}$ to $\mathrm{n}$ ). Lane $\mathrm{a}$ is $100 \mathrm{pb}$ DNA Ladder. Lane $\mathrm{b}$ is positive control ADV DNA. Lane o is negative control BHV-1 DNA. Panel B: PCR amplification of $\mathrm{gG}$ sequences of acutely infected mice (lanes $\mathrm{c}$ to $\mathrm{n}$ ). The controls are the same as in panel A. Panel C: Dot blot hibridization analysis using biotin 7-dATP proble to determine specificity of ADV DNA amplification. Ca: latent infection. Cc: acute infection. No signal was evident in negative controls for $\mathrm{Ca}$ and $\mathrm{Cc}$ (b and $\mathrm{d})$. 
field ADV strain can establish latency in the trigeminal nerve ganglia after subcutaneous rear leg inoculation in animals with circulating antibodies. Besides, the results reported here indicate the condition of optimization for the amplification of $\mathrm{gG}$ sequence and the use of non radioactive probe to confirm the specificity of the amplification product. This ADV latency model can also be further explored to design diagnostic strategies, including sensitivity detection methods, besides being a tool for optimization of the molecular diagnostic methods. In addition, the unsolved question of whether ADV latency can be established at non-neural sites and what kinds of cells are involved can be addressed. Finally, the model can be used to explore the protective quality of different kinds of antibodies in AD. One can speculate that the production of secretory antibodies will provide greater protection than circulating ones, an assumption that can also be confirmed using this model.

\section{ACKNOWLEDGMENTS}

This work was supported by grants received from the CNPq, FAPEMIG, FINEP and PADCT. R.B.F. was supported by a grant of CAPES. The authors wish to thank A. L. Cândido, M. E. Oliveira and P. P. de Barros, for their fruitful discussions.

\section{RESUMO}

\section{Infecção aguda e latente em camundongos expostos a uma amostra virulenta do vírus da doença de Aujeszky}

Infecções dos tipos aguda e latente foram obtidas em camundongos infectados com a amostra brasileira LA031 do vírus da doença de Aujeszky (ADV). A administração subcutânea da amostra de ADV irradiada com luz ultravioleta foi indispensável para se estabelecer a infecção latente. A presença do ADV em animais foi detectada por PCR. Oligonucleotídeos de 22 mer foram sintetizados e usados para amplificar sequências do gene da glicoproteína $\mathrm{gG}$ no gânglio do nervo trigêmio em camundongos com infecção aguda e latente. A especificidade da amplificação foi verificada por hibridização do tipo dot-blot.

Palavras-chave: vírus da doença de Aujeszky, reação em cadeia da polimerase; hibridização dot-blot.

\section{REFERENCES}

1. Belák, S.; Bjsallagi-Pordany, A.; Fleusburg, J. Detection of pseudorabies virus DNA sequence by polymerase chain reaction. Arch. Virol. 108: 279-286, 1989

2. Belák, S.; Linné, T.; Magyar, G.; Harrack B.; Benkö, M.; Klingeborn, B.; Klintevall, K. Bartha, A. Bovine herpesvirus 1: rapid diagnosis of infection by direct filter hybridization. Mol. Cell. Probes. 2: 147-156, 1988. 3. Beran, G. W.; Davies, E.B.; Arambulo, P.V., Will, L.A. Hill, H.T.; Rock, D.L. Persistence of pseudorabies virus in infected swine. J. Am. Vet. Med. Assoc. 176: 988-1000, 1980.

4. Carneiro V.; Cardim, W.H. A doença de Aujeszky em suínos no Brasil. Arq Inst. Biol. 18: 243-252, 1947.

5. Carvalho, R., Resende, M. Comparação de seis amostras brasileiras do vírus da doença de Aujeszky (VDA) através da análise de seu genoma com enzimas de restrição. Arq. Bras. Med. Vet. Zootec. 44: 87-95, 1992.

6. Carvalho, R., Resende, M.; Franco, G. Teste imunoenzimático (ELISA) indireto para a detecção de anticorpos contra o víurs da doença de Aujeszky (VDA) em suínos. Arq. Bras. Med. Vet. Zootec. 46: 101$111,1994$.

7. Choug, V.C.; Forster, V. Relative rates of Aujeszky disease virus attenuation, as assessed in mice. Vet. Microbiol. 15: 249-256, 1987.

8. Clements, G.B.; Subak-Sharpe, J. Herpes simplex virus type 2 establishes latency in the mouse footpad. J. Gen. Virol. 69: 375-383, 1988.

9. Davis, L.; Kuehl, M.; Battey, J. Basic methods in molecular biology, 2nd edition, Applenton and Lang, Norwalk. Connecticut, 1996, 777p.

10. Delleuw, P.W.; Van Oirschot, J.T. Vaccines against Aujeszky's disease: evaluation of their efficacy under standardized laboratory conditions. Vet. Q. 7: 191-197, 1985.

11. Galeota, W.J.G.; Osorio, F.A. Investigation on sites of pseudorabies virus latency using polymerase chain reaction. Am. J. Vet. Res. 52: 1199-1803, 1991.

12. Gustafson, D.P. Herpesvirus diseases of mammals and birds: comparative aspects and diagnosis. In: Kurstak, E.; Kurstak, C. (eds). Comparative diagnosis of viral diseases. Vol. 3. Academic Press, New York, 1981, p. 205-265

13. Hill, H.; Crandell, R.A.; Kanitz, C.L.; McAdaragh, J.P.; Seawrigy, G.L.; Solorzano, F.; Steward, W.C. Recommended minimum standards for diagnostic tests employed in the diagnosis of pseudorabies (Aujeszky's Disease). Annual Meeting of the American Association of Veterinary Laboratory Diagnosticians, Minneapolis, 1977, p. 375390.

14. Kojnok, J. The role of carrier sows in the spreading of Aujeszky's disease to sucking pigs. Data on Aujeszky's virus carriership among fattening pigs. Acta Vet Acad. Sci., Hung. 15: 283-295, 1965.

15. McCaw, M.B., Osorio, F.A., Wheeler, J., Xu, J., Erickson, G.A. Effect of maternally acquired Aujeszky's disease (pseudorabies) virus-specific antibody in pigs on establishment of latency and sero conversion to differential glycoproteins after low dose challenge. Vet. Microb. 55: 91-98, 1997.

16. Mettenleiter, T.C. Immunobiology of pseudorabies (Aujeszky's disease). Vet. Immunol. Immunopathol. 54: 221-229, 1996.

17. Osorio, F.A.; Rock, D.L. A murine model of pseudorabies virus latency. Microbial Pathog. 12: 39-46, 1992.

18. Rea, T.J.; Timmins, J.G.; Long, G.W.; Post, L.E. Mapping and sequence of the gene for the pseudorabies virus glycoprotein which accumulates in the medium of infected cells. J.Virol. 54: 21-29, 1985.

19. Rock, D.L.; Fraser, N.W. Detection of HSV-1 genome in central nervous system of latently infected mice. Nature 302: 523-525, 1983

20. Shope, R.E. An experimental study of "mad itch" with special reference to its relationships to pseudorabies. J. Exp. Med. 54: 233$248,1931$.

21. Van Oirschot, J.T. Vaccination and control of Aujeszky's disease. Kuwer Academic Press, Boston, Mass. 1989, 412 p.

22. Vidor, T.; Cunha, A.C.; Guizzardi, I.I.; Salvo, E.O; Martins, R.M.; Fernandez, G.V. Doença de Aujeszky: Uso do camundongo em teste de eficiência da vacina inativada. Arq. Bras. Med. Vet. Zoot. 43: 387396, 1991.

23. Volz, D.M.; Lager, K.M.; Mengeling W. L. Latency of a thymidine kinase-negative pseudorabies vaccine virus detected by the polymerase chain reaction. Arch. Virol. 122: 341-342, 1992.

24. Worden, A.N.; Lane-Petter, W. The UFAW handbook on the care and management of laboratory animals. UFAW, London, 1959, 326p. 